\title{
A Feminist Perspective on Religion in Polygynous Families in KwaZulu-Natal
}

\section{Zamambo Mkhize \\ ORCID iD: https://orcid.org/0000-0002-4486-3882}

\begin{abstract}
According to statistics, Christianity is the religion with the highest following in South Africa. It is known that religion plays a significant role in culture and society as a whole. Polygyny has been extensively researched from many vantage points, however, these studies have mainly been from a Middle Eastern perspective, not from a Zulu cultural perspective. In the Middle East, culture and tradition are based on the religion of Islam and, in turn, Islamic religion informs culture. In contrast, in the Zulu culture, someone can be a Christian while continuing to adhere to beliefs in amadlozi (ancestors), in spite of the latter being against Christian teaching. For some Zulu people, religion and culture are deeply intertwined - their culture is their religion and vice versa. Using an interpretivist paradigm within a qualitative methodology, this study interviewed 10 female adults who had been raised in polygynous families, to determine how their religion impacted their identity. This study was carried out in Hammarsdale, KwaZulu-Natal, all the participants had been formally educated, and the study was underpinned by social constructionism and African feminism theories. The finding is that religion and culture are two sides of the same coin in relation to their position on women's subordination. This paper aims to foreground how the Christian religion impacts on women raised in polygynous families.
\end{abstract}

Keywords: Gender, identity, KwaZulu-Natal, polygyny, religion 


\section{Introduction}

Religion and its position on family, gendered division of labour and culture has remain unchanged through space and time. Polygyny ${ }^{1}$ is referred to in the Holy Books of Judaism, Christianity and Islam. In the Christian bible, the practice of polygyny is not outright sanctioned because the old testament speaks of certain men who practised polygyny, instead, it is absolutely condemned in the new testament, which makes the relationship between polygyny and Christianity an uneasy one. Polygyny has been extensively researched from many different vantage points, among which polygyny's impact on children, women and men, but this research has mainly been from a Middle Eastern perspective. Furthermore, research has largely overlooked the role of religion in forging identities for individuals and groups who were raised in polygynous families. Scholars, such as; (Al-Krenawi \& Graham 1999; Al-Krenawi \& Lightman 2000; Al-Krenawi \& Slonim-Nevo 2008; Peek 2005), researched how certain influences, such as polygyny and religion have a direct impact on children raised in polygynous families. In Peek's (2005) study, younger children often identified according to their parents' national and ethnic backgrounds. Individuals absorbed and internalised norms, values and behaviours they observed being exemplified by their parents, peers and others, long before they understood these norms, values and behaviours intellectually.

Religion in this study refers to the Christian religion, including its beliefs. Religion and Christian will be used interchangeably. Religion itself is gendered, because of the differences in the roles of men and women within the Christian religion (Madge, Hemming \& Stenson 2014). This research sought to understand how this inherently gendered bias contributes to the identity of women who were raised in polygynous families. Literature is silent on the impact religion, specifically Christianity, has on women who were raised in polygynous families and how this upbringing, in turn, affects their identity. Therefore, this study aimed to understand how women raised in polygynous families constructed their identities within their Christian faith as

${ }^{1}$ In principle, there are three forms of polygamy: polygyny, in which one man is married to several wives; polyandry, where one woman is married to several husbands; and group marriage, in which several husbands are married to several wives - the latter is a combination of polygyny and polyandry (Zietzen 2008:3). 


\section{Zamambo Mkhize}

well as their Zulu culture. This research was qualitative in nature and was located in Hammarsdale in the province of KwaZulu-Natal. This study was underpinned by two theoretical frameworks: Social constructionism and African feminism. This paper begins by referring to the literature, after which the theoretical leanings and the methodology will be discussed, followed by the discussion of the data and conclusion.

\section{Literature Review}

Scholars, such as Bernal (1994), attest that, while gender has been historically and socially constructed based on local realities, religious systems have remained timeless, monolithic and rigid. Religious doctrine and practices, however, continue to be renegotiated under changing historical circumstances (Bernal 1994:37). According to Al-Krenawi and Graham (1999), Islamic law and traditional culture is one and the same thing. In the Middle East, culture and tradition are based on the religion of Islam and, in turn, the Islamic religion informs the culture. There is no clear distinction between Islamic culture and religion, as there is in the Zulu culture, where one can be a Christian as well as follow the beliefs in amadlozi (ancestors), which goes against the teachings of the Christian faith. Nevertheless, for some Zulu people - not all - religion and culture are deeply intertwined: their culture is their religion and vice versa.

Religion is an intriguing topic, because it is usually imposed on the child by the parents at the child's birth; as the child matures, they may become more and more indoctrinated into that religion. According to Madge et al. (2014), if individuals break away from the religion they were raised in, it could have disastrous consequences, and result in the child being ostracised from family, culture and, ultimately, the society in which they live.

According to Ojong and Muthuki (2010:14), religion is a major determinant of people's personal choices and attitudes, and it influences believers to choose certain forms of behaviour and conduct over others. The authors assert that people practice a particular religion because all members of their society have been socialised to believe in that religion. Religion and culture put forth similar views regarding gender inequality and female submission. The scholars Ojong and Muthuki (2010:15) emphasise that culture is viewed as a collective phenomenon that shapes people's social environment. Culture influences the environment in which a person is raised, 
and this reinforces their dominant patterns of thinking, feeling and acting in other spheres. Culture also involves collective socialising of the mind, which distinguishes the members of one group from people of another (Ojong \& Muthuki 2010:15). This collective socialising encompasses both the social and the cultural, which articulates itself by influencing members of a family, their lineage, their village and their community (Ojong \& Muthuki 2010:15).

Many scholars (Butler 1993; Connell 1987; Lacan 1982; Stoller 1986; West \& Zimmerman 1987) who studied issues of identity, focused on social and cultural influences only; rarely did they pay attention to the relationship between religion and identity. Religion is a key determinant of personal choices and attitudes of people; and it shapes identity. Muthuki (2010) states that religion affects us privately, in terms of our personal attitudes and views of life, which, in turn, has a bearing on the way we live our outward lives. Some people construct part of their identity by drawing on their religion, and their religious beliefs have a great impact on the lives they chose to live. This paper seeks to explore the role religion played in the lives of women raised in polygynous families.

\section{Research Methodology and Methods}

This article emerged from two larger studies conducted by the researcher, titled Polygyny and Gender: The Gendered Narratives of Adults Raised in Polygynous Families (Mkhize 2016), and Polygyny and Gender: Narratives of Professional Zulu Women in Peri-Urban Areas of Contemporary KwaZulu-Natal (Mkhize 2011). This study employed a qualitative research methodology within an interpretivist framework. A qualitative methodology was best suited for this study, because of the emphasis on rich description, understanding and explanation of complex phenomena (Creswell 2009). An interpretivist framework was utilised, because it is a communal process involving the presentation of the participants' realities from their own viewpoints (Henning, Van Rensburg and Smith 2004).

The study was located in Hammarsdale, a peri-urban area in the province of KwaZulu-Natal, South Africa (Adam 2001; Adell 1999; Lawn, Bekker, Middelkoop, Myer and Wood 2006; Mkhize 2011). For this qualitative study, non-probability, purposive sampling was used. Purposive sampling allowed for the selection of participants whose qualities or experiences would contribute to understanding the phenomena in question 


\section{Zamambo Mkhize}

and, therefore, were valuable (Marshall 1996). The study employed in-depth interviews over a period of one year, from July 2013 to July 2014, to elicit rich qualitative data. In conducting in-depth interviews, the researcher used open-ended questions to enable participants to reflect on and give detailed accounts of their polygynous family experiences that pertaining to their religious upbringing, and how it influenced their identities. The researcher made use of particular ethnographic tools, such as repeated in-depth interviews.

A sample of ten adult women, ranging in age from 18 to 56 years old and who had been raised in polygynous families was used in this study, to enable an in-depth investigation and to elicit rich qualitative data. The lowest educational qualification was Matric, and the highest a Master's degree. Educational level was important in the study, because the researcher wanted to separate the study from related studies done on polygynous families. The researcher decided to focus on adults rather than children of polygynous families, because adults are mature enough to be able to reflect on their experiences and how their gendered identities were challenged, reaffirmed and reconfigured over time. The participants in this study were all Christian and they worshiped in different denominations.

The consent of the participants was sought at every level once the purpose of the research had been explained to them. The informants were assured of confidentiality and that they had the right to choose whether to participate or not at any time. Participants' names and identities were replaced by pseudonyms, and any distinguishing characteristics were removed for the purposes of anonymity. Interviews lasted between 45 and 90 minutes. The interviews were then transcribed manually, ${ }^{2}$ and responses were analysed for content and discourse. Transcriptions were done in tandem with the data generation process.

Thematic and narrative analyses were used in this study. This form of analysis fit in with essentialist and constructionist paradigms, and has the

2 This process involves the researcher taking voluminous amounts of information and reducing it to certain patterns, categories or themes and, then, interpreting this information by using some schema. Creswell calls this decontexualization and recontextualization. This process results in a 'higher level' analysis, and 'while much work in the analysis process consists of 'taking apart' (for instance, into smaller pieces) the final goal is the emergence of a larger, consolidated picture' (Creswell 1994:154). 
potential to provide rich, detailed and complex accounts of data (Aronson 1995:4; Braun \& Clarke 2006:5). Narrative analysis was also used to refer to accounts of personal experiences or the experiences of others (Smith 2000:328). The functions of narratives, such as reflecting back on events and talking about them, can provide meaning and coherence to and perspective on personal experience and social traditions; construct a person's knowledge, including a person's sense of self or identity; and bring about emotional adjustment and healing.

As resourceful as in-depth interviews can be, they can also be limiting in the sense that the respondents' verbal answers to questions may actually differ from what they practiced in reality. The researcher attempted to overcome this limitation by engaging with participants and probing further into their answers to elicit hidden meanings and to ascertain if their answers truly reflected what they had meant, or if it was implied.

\section{Theoretical Framework}

This study was underpinned by two theoretical frameworks: Social constructionism and African feminism. The social constructionist theory advances the notion that gender is socially constructed, and depends on location, context and time. African feminism was applicable to this study because it aims to expose the difference in the way gender is conceptualised in Africa as opposed to the West.

\section{Social Constructionism}

In attempting to make sense of the social world, social constructionists view knowledge as constructed as opposed to created. Society is viewed as existing as both a subjective and an objective reality (Andrews 2012). Feminists claim that gender is a social construction, which means that people's dispositions and ideas about gender are not predetermined by their biological sex differences. Ideas about gender and the social practices that gender institutionalises are alterable, indicating that gender is variable from culture to culture and is, therefore, socially constructed (Conrad \& Barker 2010). Gender is achieved and constructed through psychological, cultural and social means (West \& Zimmerman 1987). According to West and Zimmerman (1987), socialising gender means creating differences between girls and boys, 


\section{Zamambo Mkhize}

women and men. These differences are not natural, essential or biological, but once the differences have been constructed, they are used to reinforce the 'essentialness' of gender.

According to Berger and Luckmann (1991), socialisation is defined as the comprehensive and consistent induction of an individual into the objective world of a society or a sector of it. Primary socialisation is the first socialisation an individual undergoes in childhood, through which they become a member of society. Secondary socialisation is any subsequent process that inducts an already socialised individual into new sectors of the objective world of their society. It is evident that primary socialisation is the most important one for an individual, and forms the basic structure of all secondary socialisation, which has to resemble that of primary socialisation. This is where cultural practice of patriarchy, and religion, would be introduced to the child.

Lacan (1982) provides a key for understanding the socialisation and symbolisation processes that have shaped women's specificity through the ages. For Lacan, identity does not derive from genetic predispositions or from an unfolding of neuro-psychological developmental sequences, nor is it the product of a war between biological and cultural forces or the reflection of collective archetypes. Identity, in Lacan's understanding, is built up as a composite of images and effects, i.e., mental representations, taken in from the outside world from the start of life, which are developed in relation to the desire for recognition and, later, social requirements for submission to an arbitrary law, which illustrates that identity is constructed and not biological or inherent (Lacan 1982:7).

\section{African Feminism}

Western feminism fails to effectively represent and cater for African women, because Western feminism does not acknowledge the agency and potential of African women. The African feminist, Obioma Nnaemeka (2005), states that the issue of balance is neglected in the one-dimensional Western constructions of African women, who are usually viewed as poor and powerless. African women are depicted as confined, powerless and unable to 'control their lives'. African intellectual feminism, in turn, is criticised for being elitist and pro-Western, whilst popular African feminism is rooted in the lived experiences and cultural beliefs of African women, but fails to 
mobilise against cultural practices that are oppressive. It is difficult to reduce all strands of feminism into a single theoretical context, because of their inherent differences (Nnaemeka 2005).

African feminism offers a different theorisation around family and gender relations than that of the West. Unlike in the West, where power lies with the male gender only, in African society, the principle of seniority is paramount and whomever is the most senior in the room, wields the most power, regardless of gender (Oyewumi 2000; 2002). According to Nnaemeka (2005), African feminism is about negotiating with the male gender. Negofeminism, a term coined by Nnaemeka, is a feminism of negotiation; a feminism that knows when, where and how to negotiate around patriarchy, or go around it in different contexts. It is a 'no ego' feminism, a feminism that calls on African women to find creative ways to combat gender inequality within their cultures. Nnaemeka (2005) argues that African women understand that the African man is not the enemy, but a potential ally that one needs to constantly negotiate with in order to enact gender equality. Negofeminism is a type of African feminism aims to highlight the differences between how gender is conceptualised in Africa and the West, and how Africans have learnt to negotiate their gendered positions. These two theories were best suited for this research and complemented each other.

\section{Zulu Culture and Gender Identity}

In every culture, the individual internalises a culturally shaped gender polarity that directs them to develop, in some measure, qualities attributed to their own sex, and to suppress qualities of the other sex. Culture plays a pivotal role in interfacing with the psychodynamics of gender identity (Diamond 2006:1104). Hammarsdale in KwaZulu-Natal is a predominantly isiZulu-speaking area. It is a peri-urban area, meaning it represents a mixture of rural and township life. As a result of this environment, traditional roles are reinforced, but since it also has a township quality, modern, progressive roles are also accepted. Zulu culture is patriarchal and rooted in deep traditional customs. In a traditional Zulu home, the father is the head of the household, and boys enjoy more privileges than girls in the family, because boys will continue the family name.

In the past, men have held the belief that Zulu culture does not permit women to be active in the public space, or to be equal to men. Zulu men have 
argued that, in Zulu culture, women are inferior to men and should never challenge men when it comes to issues of politics, because politics is culturally a man's domain. Thus, Zulu culture, both implicitly and explicitly, promotes the idea that men are superior, which makes it gendered in nature (Mkhize 2011).

\section{Religion Married to Culture}

In Zulu culture, religion and culture, at times, appear to be two distinct spheres. Religion is revered and culture is respected. Religion is viewed as working simultaneously with culture. Zulu people believe there is a God, uNkulunkulu (The Great Ancestor). According to Ntshangase (2018: 238) ancestors are people who are not lifeless, but people whose spiritual bodies have moved from the world of the living to the world of the dead, hence they are called 'living dead'. Their passing to the spiritual world does not sever the tie with the living (Ngidi 2012:2). In pre-colonial times, the Zulu people believed that, when a person died, they became an ancestor who becomes a spokesperson or representative for them with a higher power (God). The ancestor would be the representative for the living to this higher power. There is a misconception that Zulus worship their ancestors; in actuality, Zulu people venerate their ancestors, because they believe that their ancestors speak to God directly on their behalf, therefore, angering or displeasing an ancestor in any way would have negative consequences.

This unique way Zulus understand God and religion, and the role their ancestors play in it, exposes how religion and culture is intertwined as one entity. However, Christian religion emphasises a patriarchal system, in which men are superior of women. Zulu culture never organically practiced such a ridged gender divide. According to African feminists (Muthuki 2010; Nnaemeka 2005; Oyewumi 2002), African culture before colonisation had a more egalitarian system, in which genders had their specific roles and no one role was superior to the other. One could argue that the female gender had significant power within the family, especially in a polygynous family; however, the power was dependent on the ranking of the wife (first, second, etc.) and their seniority within the family (Mkhize 2016). Colonisation and the introduction of the colonisers' religion violently enforced a rigid and static patriarchal system that oppressed and continues to oppress women. 


\section{Sineke}

My church promotes culture and tradition and therefore I am happy about my polygynous marriage.

In the quote above, one can see that religion and culture are one and the same thing. Religion promotes culture and culture promotes religiosity. This finding indicates how religion and culture are deeply intertwined. One participant stated her religion played a significant part in her remaining in her unhappy polygynous marriage, because her faith compelled her to be a peaceful person and to avoid having enemies. Another participant said she believes nothing happens without God having sanctioned it and, therefore, her marriage, regardless of her happiness, was a gift from God.

\section{Religious Control and Resistance}

According to Cruz (2015), African women conform to their religion and culture whilst simultaneously resisting it. African women resist in various ways, of which silence is one. African culture socialises women to be silent, and not to be vocal. A good African woman in African culture is a woman who is quiet and pious. However, silence can also be viewed as a hidden voice. Cruz (2015:21) states that silence is an effective resistance strategy. Silence is also a strategy used by African feminists, especially in negofeminism. Nnaemka (2005) describes nego-feminism as a feminism that negotiates with the African man. Negotiating means understanding when to be silent on certain issues, and when to be vocal on others. In African society married women are socialized to be respectful and reverent. In Zulu culture the extended family plays a significant role in the marriage of two people and if issues arise, the married woman has multiple individuals she can seek help from with her martial issues. Therefore, silence is encouraged as an effective resistance strategy, because one is silent not because they condone certain actions, but because they know other family members will voice their objections on their behalf whilst they remain respectable. African women also resist the oppression they face in their religious or cultural settings through solitary prayer, prayer gatherings with other women and senior family members, in their own, unique ways. Another way they resist is through being educated. Education offers African women opportunities for emancipation through being exposed to various forms of knowledge, 
knowledge communities and communities in practice that support women and aid in resistance.

\section{Duduzela}

I was unhappy in my marriage and I wanted to leave. The church threatened to remove me from the congregation if I left my polygynous husband. Shembe promotes this type of union.

The quote above shows vividly the explicit threat her church used to instil fear and enact control over the participant. Duduzela was unhappy in her marriage because it became polygynous without her consent. Her husband did not follow the correct cultural procedures to take a second wife. The second wife was imposed on Duduzela, and that made her unhappy. Her church used her religion and fear of God to prevent her from leaving an unhappy marriage; one could argue that this type of threat was cult-like. ${ }^{3}$ Unfortunately, the type of negotiation nego-feminism refers to is not possible in the case of these types of threats against women. How can women who oppose the church's wishes, such as on divorce, negotiate in the face of overt threats of excommunication? This threat goes against African feminism's assertion that the African man is not the enemy, but an ally in the fight for gender equality and women's well-being. The African man is the leader of the Shembe church, and is complicit in keeping women oppressed within the church.

\section{Anele}

I was told by my grandmother that getting married is a gift from the ancestors and no matter how difficult it gets I must persevere because it was a blessing from God to find a husband.

\footnotetext{
${ }^{3}$ The term cult comes from Latin, Cultus, meaning worship. The term can be extended to the worship of secular objects and also implies an excessive, unbalanced belief in or craze for anything. When applied to a religious context, the term refers to any set of people bound together by devotion to a particular sacred person/object/ideology. It also means any religion considered false, unorthodox or spurious (Ellwood 1986:1). Today, the term has negative connotations, including controlling, abusive and threatening to a congregation.
} 
One participant said, regardless of hard she tried to leave her polygynous marriage, the church always warned her that she would be going against God, and that the Bible says she must love her husband through good and bad times. Another participant said she was told that, once married in a polygynous marriage, that she would never ever be allowed to leave, because she was bound by church regulations to stay in the marriage and respect the husband no matter what he does; if she leaves the marriage, she will also be leaving the church. Quotes by other women in the study explain how religion and the church, specifically, has operated in their lives. Women were overtly oppressed by being told explicitly that leaving the marriage, means, in essence, leaving the church. This type of church system is, in effect, using religion to control women and prevent them from exercising their agency or free will to leave unhappy unions. Anele's quote is telling, and shows how religion and culture are intertwined, because her grandmother reiterated that being married is a gift from God and the ancestors. This exhortation would make it difficult for a woman to leave an unhappy union, because she would not only be angering God, but her ancestors too. The fear instilled in women makes them reluctant to divorce, and their religion and culture conspire to keep them in the union. Anele's quote also shows how women appear to be complicit in their own oppression. Anele's grandmother is perpetuating a certain type of socialisation that imprisons women in unhappy marriages. African women and African feminists have been criticised by Western feminists for being compliant to patriarchal oppressions they face, and not taking radical steps to reconfigure and resist. Western feminists do not acknowledge that the way African feminists resist involve a different type of activism, which does not make it any less effective in the long term.

However, religion was not viewed as oppressive by all participants. One participant stated that she used religion as a coping mechanism - in difficult times, she found solace in prayer. Some women used religion as a refuge in their hardship - they did not see it as an oppressive system. Cruz (2015) states that women could resist by organising gatherings in church and having prayer groups. By doing so, women used the church and their religion, a structure of their oppression, to enact their agency and resistance to it.

\section{How Religion is Engaged}

Sullins (2006) states that women tend to be more religious than men on every 
measure of religiosity. Sullins (2006) argues that religious behaviour is encouraged because it relates to obtaining women's commitment or relegation to the domestic sphere. The prevailing assumption among sociologists is that gender differences in both religiousness and social location as adults are underpinned by broad cultural mechanisms of differential socialisation processes that pattern men and women into different sets of values, roles and norms for behaviour. The findings of Sullins' (2006) study are in contrast to what the research results of this study found.

\section{Qondeni}

My mother was a religious woman and she always made us go to church even when we did not want to. We worshiped in a Zion church and I hated religion because it justified polygyny in that it was practised in the Bible. I would always debate with my mother that yes polygyny was practised in the Bible but it was in the Old Testament and that even God changed his mind and realised the detriment that polygyny caused on women and their children in the New Testament. I think Islam has it correct in that it does not support polygyny per se but states that a man cannot take on additional wives if he cannot treat them equitably. That in itself was a veiled protest against polygyny because no one can treat more than one person equally at the same time, it is impossible. I think my mother used religion as a shield or comfort for her in her marriage. Religion has been used to justify inequality of the genders and I have a hard time reconciling that with my individual rights as a free woman in a free country.

The participants explained that their religious denominations had different stances about the practice of polygyny. The Catholic, Anglican and Protestant denominations were opposed to polygyny, while the Shembe and Zionist denominations were proponents of polygyny; still other churches were ambivalent about the practice. The respondents stated that it was difficult to reconcile the their church's opposition to polygyny while they lived a polygynous lifestyle. One participant stated she felt like a hypocrite. The participants were aware of the contradictions of religious doctrine and gender equality, in the same way as they highlighted the contradiction between the country's constitution, which refers to equal rights, and their culture, which 
does not necessarily espouse equal rights for women. They stated that religion and culture are two sides of the same coin in relation to their position on women's subordination. One respondent stated that religion is less criticised for its stance on gender inequality, because it is considered to be holy and the word of God, but culture is man-made, and should be criticised more for its sexism.

Many of the participants credited religion as the 'saviour' of their 'unusual family lifestyle', and many had turned to religion when their lives had become particularly difficult. Some even said that their identity would have been different if they did not have religion in their lives. Their religion was a large part of their lives and, therefore, part of their identity as women. Although some did claim that religion was initially forced upon them when they were young children, these participants said that, when they became adults, they chose to continue with it. It is important to emphasise that these women are highly educated and, therefore, could be critical of both religion and culture. However, in spite of criticism, they continued to uphold religious and cultural traditions. This behaviour goes against what liberal feminists believe, namely, that if women are educated they will be emancipated and empowered in their lives. Liberal feminists, however, fail to acknowledge that African women, in spite of being educated and empowered, may still be oppressed in their cultures and religion.

\section{The Impact of Religion on the Negotiation of the Female Identity}

The sociology of gender and religion first emerged in the 1970s and 1980s, with feminist critiques of religion, on the one hand, and studies of issues such as women's ordination and goddess worship, on the other. Reflecting on the history of gender scholarship more generally, much of this work was produced by women sociologists who were politicised by the women's movement and who turned a critical eye to women's experiences within various religious traditions (Avishai, Afshan \& Rinaldo 2015).

According to Avishai et al. (2015), religion is used to reinforce patriarchal norms. The authors explain that orthodox Jewish women in Israel express agency as they 'do religion', living up to rather than challenging strict religious norms. This shows that religious masculinity, like religious femininity, is being restructured in response to contemporary political, econo- 
mic and cultural realities (Avishai et al. 2015).

\section{Thuleleni}

I believe the one way to combat this 'resistance' to religion and its many rules which are usually forced or expected of females [and not males] is to live up to them. I think if a woman is a God fearing, pious woman she is living up to and more to what is expected of her faith and that in a way could be a form of agency. I think patriarchy is designed for women to fail. Women are expected to be 'perfect' and no one can achieve that so if you come close you are respected and revered.

Thuleleni chooses to enact her African feminism in a unique way, by using conformity as a form of resistance. Her way of combating religion is by living up to the high standards imposed on her. Thuleleni's identity is tied to being a good, Christian, Zulu woman. She confirms the issues raised in the literature, namely, that, in some orthodox religious societies, women are not 'oppressed' to the extent that Western feminists believe, because these women use their religion to enact their agency; doing so enables them to find freedom in this and not oppression. Thuleleni believes if she lives up to what is expected of her as a Zulu woman, and she is empowered through education and financial security, she will be enacting agency within her culture. Thuleleni also believes that, if she does not conform to her traditional gender role, she will be fighting a losing battle, because the patriarchal system is designed to place women on such an impossibly high pedestal that it is actually impossible to meet the expectations of perfection. However, the more a woman behaves in accordance with religious gender ideals, the greater reverence and respect she is accorded within her culture.

Thuleleni's quote is fascinating because it is contradictory. She completely understands how oppressive religion and her culture are, and that they impossibly high standards are set for women. Thuleleni has realised that going against the standards would be more detrimental to her than working to attain and maintain the standard expected of her. She is grappling with religious expectations, and even though she is educated and empowered, she still feels powerless. Her experience is the opposite of what liberal feminist believe, namely that, if women are educated they will be empowered. Liberal feminists fail to realise that African women, even if they are educated, are 
still oppressed by their religions and culture. One could argue that Thuleleni's failure to criticise the impossibly high standards set for women, instead doing everything expected of her, so that she is considered to be a good, Christian, Zulu woman, she is, in effect, sanctioning the expectations. Her silence could be understood as either shouting complicity in her oppression, or resisting it.

Without assuming a deterministic framework, it may be productive to consider how gender and religion constitute each other. For example, to understand orthodox Jewish women's agency, or Muslim femininity, it is necessary to examine how these categories are created and operate within certain historical and cultural contexts. The suggestion that scholars (Avishai et al. 2015) put forward is that scholarship on gender and religion would benefit from theoretical perspectives that build on current theories in the sociology of gender, including conceptualising gender and sexuality as constituted through practice and interaction, informed by cultural narratives and institutional contexts, and as profoundly relational and intersecting with other categories, such as race and class. This proposal was confirmed by the participants, because some participants stated that they had agency and were able to exercise it within their religion as well as within their culture.

Thuleleni's quote also incorporates that part of African feminism that acknowledges constant negotiation as a form of resistance to patriarchy. If women live up to the ideal of women, they are, in effect, exercising their agency, because they can never be faulted. Thuleleni's quote is in agreement with the social constructionist theory, in that gendered identity is constructed, therefore, the female identity is constructed according to its environment.

\section{Religion Used for Finding a Life Partner}

Religious boundaries and meaning are constructed both from within and without, in response to internal conflicts and choices and external pressures and rewards that drive identity formation (Peek 2005:236). The participants stated that they wanted their future spouses to follow some sort of religion, because this would indicate that they had had a good upbringing, and also had respect.

\section{Shongani}

My fiancé is not very religious but he does attend church with me sometimes. He says he was raised in a household where everything 
was about church and he got tired of it so as an adult he did not care too much about the church. He says he attends church for me because religion is important to me. I am OK with that at least he is respectful of religion and hopefully if we have children they too will be religious. My religion is against polygyny but they would never state that publicly because members of the congregation are polygynous and they would be offended. I would choose my religion if I had to decide between cultural traditional practices and Catholicism because Jesus came to save us and show us the true correct way of life and not follow archaic and arbitrary practices.

\section{Phakimpi}

Religion is like culture if you do not observe or respect it you are not an intelligent person. Yes there are parts of religion I do not like or disagree with just like there are traditional customs I am vehemently against but it is God and it is bigger than me so I will respect it. If it was good enough for my parents it is good enough for me. I am torn because I want to respect my culture because my ancestors did but I want to worship God because I am Anglican and I believe.

The participants combined their Christian religion with their Zulu culture, though some placed religion above culture and others believed culture came before religion. It was important for the participants that their spouses or future spouses respect religion. Even if their potential spouse was not as religious as they were, the participants wanted the future spouse to believe in some sort of religion. Therefore, participants' religious beliefs impacted on the participants' choice of partner, current or future. Participants understand that religion is sometimes contradictory, and some indicated that they do not know what they would choose if they had to choose between their culture and their religion. Some respondents stated that they would choose their $\mathrm{Zulu}$ traditional practices, others would choose their Christian belief system, and others wished to be able to practice both. Religion is an important facet of their lives. Some participants' religion had been forced upon them growing up, and when they became adults, they made the decision to either continue with their religious practice, or to abandon it. Some who left the church mentioned that now, later in life, they have returned to their religion. Therefore, it can be argued that age and maturity have a bearing on a person's religious 
beliefs. The women in this study still viewed religion as a vital component of the way they constructed their identities as Zulu women, as well the way they chose their future partners. These women, despite their education, chose to find partners who are religious and, in theory, would oppress them. Since religion promotes a patriarchal system in which women must submit to their husbands, these women actively sought out religious partners who would perpetuate their oppression within their religion. So, religion continues to be an invisible force, even when women chose their partners.

\section{Discussion}

The women who participated in this study are all highly educated - some even had postgraduate degrees. Despite their education and qualifications, religion had a significant hold over their lives. Education was an important element of the study, because the author wanted to emphasise that, despite being educated, women were still bound within their socio-cultural environments and influences, such as religion. These women had been raised in polygynous families, and were aware of how inherently discriminatory the practice of polygyny was, but they never overtly criticised it. They just stated it was a traditional cultural practice that the either church sanctioned or ignored, depending on their denomination. Religion and culture directly influenced their decisions, including choosing their life partners. The remarkable part is that these women wanted partners that were also religious. They wanted partners who, according to the requirements of their religion and culture, they would have to submit to. These women, although critical of religion and culture in relation to how religion and culture are deeply intertwined and complicit in controlling women, still adhered to the expectations their religion and culture had of them. Interestingly, these women found unique ways of enacting their agency and opposing patriarchy. Some women chose to be silent as a way of resisting. Thuleleni chose to maintain the high expectations expected of her as a Christian Zulu woman. These strategies are in line with the African feminist theory of negofeminism, according to which African women understand the need to be creative to fight their oppression. African women understand that the African man is not the enemy, and that they need to work together to achieve a more gender-equitable society.

Foucault's (1972) theory on power was useful in informing the 


\section{Zamambo Mkhize}

author's own understanding of power. Foucault views power as constantly moving systems of unequal force relations. It was interesting to see how some female participants moved from the one system of control (culture) to another (religion). The participants, although highly educated, understood what their religion was actually promoting. They knew they should not appear to criticise their religion or culture, though they did voice their dissatisfaction with certain aspects. It was curious to note that, because the participants followed the Christian religion as well as their traditional cultural practices, they wanted their spouses or future spouses to also adhere to these practices. There was, thus, a sort of contradiction: They followed a religion they deemed, at times, to be oppressive to women, but they were wary of partners who did not follow any religion at all. This contradiction has not been explored in literature, except to state that patriarchy is so salient to these women that even the idea of going against a patriarchal system, such as the church, makes them fearful.

\section{Conclusion}

Christianity has the highest following in South Africa, making its influence amongst the Zulu people significant. The participants in this study believed that, even though religion is gendered, it is justified, because it is the word of God, therefore, it is holy and cannot be criticised. In contrast, the Zulu culture can be criticised, because it is man-made. Participants believed that gender differences as espoused by religion cannot be changed because it is Holy, but culture is not divine and, therefore, it can be changed. It can be argued that religion is socially constructed to encapsulate socio-cultural meanings and practices. Religion is used as a way to keep women in submissive positions, whilst the patriarchal Zulu culture reiterates that submissiveness. So, religion and culture are deeply intertwined in societal culture. Some participants viewed religion as a 'saviour', and others had negative conceptions of religion, because it was a 'partner' of culture in attempts to keep women in subservient positions. Some respondents stated that they were opposed to polygyny and sometimes religion was used by the participants to justify this sentiment; nevertheless, they acknowledged that their traditional practices had been entrenched before the missionaries came to Africa, and for this reason, they supported the practice of polygyny. Historical analysis has shown that, although culture is dynamic and has evolved over time to allow 
more gendered freedoms within the Zulu culture, the role of women has remained consistently static. Certain aspects of religion have been used to advocate for a more egalitarian gender system within the Christian church, but change has moved at a glacial pace. Some of the women in this study found comfort in their religion, and other women found confirmation of what it means to be a good Christian woman. Religion and culture seemed to blend well in affirming traditional, gendered Zulu roles.

\section{References}

Adam, M. 2001. Definition and Boundaries of the Peri-urban Interface: Patterns in the Patchwork. In Drechsel, P. \& D. Kunze (eds.), Waste Composting for Urban and Peri-urban Agriculture. Wallingford: CABI Publishing.

Adell, G. 1999. Theories and Models of the Peri-Urban Interface: A Changing Conceptual Landscape. London: Development Planning Unit. Al-Krenawi, A. \& J.R. Graham 1999. The Story of Bedouin-Arab Women in a Polygamous Marriage. Women's Studies International Forum 22,5: 497 - 509. https://doi.org/10.1016/S0277-5395(99)00054-0

Al-Krenawi, A. \& E. Lightman 2000. Learning Achievement, Social Adjustment and Family Conflict among Bedouin-Arab Children from Polygamous and Monogamous Families. The Journal of Social Psychology 140.,3: 345 - 355.

https://doi.org/10.1080/00224540009600475 PMid:10902375

Al-Krenawi, A. \& V. Slonim-Nevo 2008. Psychosocial and Familial Functioning of Children from Polygynous and Monogamous Families. Journal of Social Psychology 148, 6: 745 - 764.

https://doi.org/10.3200/SOCP.148.6.745-764 PMid:19058661

Andrews, T. 2012. What is Social Constructivism? Grounded Theory Review 11,1.

Aronson, J. 1995. A Pragmatic View of Thematic Analysis. The Qualitative Report 2,1: 1-5. https://doi.org/10.46743/2160-3715/1995.2069

Avishai, O., J. Afshan \& R. Rinaldo 2015. A Gender Lens on Religion.

Gender \& Society 29,1: 5 - 25.

https://doi.org/10.1177/0891243214548920

Berger, P.L. \& T. Luckmann 1991. The Social Construction of Reality: A 
Treatise in the Sociology of Knowledge. London: Penguin Books.

Bernal, V. 1994. Gender, Culture, and Capitalism: Women and the Remaking of Islamic 'Tradition' in a Sudanese Village. Comparative Studies in Society and History 36,1: 36 - 67.

https://doi.org/10.1017/S0010417500018880

Braun, V. \& V. Clarke 2006. Using Thematic Analysis in Psychology. Qualitative Research in Psychology 3,2: 77 - 101.

https://doi.org/10.1191/1478088706qp063oa

Butler, J. 1993. Bodies that Matter: On the Discursive Limits of Sex. London: Routledge.

Butler, J. 2011. Gender Trouble: Feminism and the Subversion of Identity. Routledge. https://doi.org/10.4324/9780203824979

Connell, R. 1987. Gender and Power. Society, the Person and Sexual Politics. Stanford University Press.

Conrad, P. \& Barker, K. 2010. The Social Construction of Illness: Key Insights and Policy Implications. Journal of Health and Social Behavior 51, 1 Supplment: S67 - S79.

https://doi.org/10.1177/0022146510383495

PMid:20943584

Creswell, J.W. 1994 Qualitative and Quantitative Approaches. New York: SAGE Publications.

Creswell, J.W. 2009 Research Design: Qualitative, Quantitative and Mixed Methods Approaches. $3^{\text {rd }}$ Edition. Thousand Oaks, CA: Sage.

Cruz, G.T. 2015. Asian Women's Hidden Transcripts: Theological and Pastoral Perspectives. New Theology Review 27,2: 19 - 26.

Diamond, M.J. 2006. Masculinity Unravelled: The Roots of Male Identity and the Shifting Male Ego Ideals throughout Life. Journal of the American Psychoanalytic Association 5, 4: 1099 - 1130.

https://doi.org/10.1177/00030651060540040601

PMid:17354489

Durkheim, E. 1912. The Elementary Forms of the Religious Life. Swain, J.E. (trans.). London: Allen \& Unwin.

Ellwood, R. 1986. The Several Meanings of Cult. Thought: Fordham

University Quarterly 61,2: 212 - 224.

https://doi.org/10.5840/thought19866123

Engels, F. 1839. Letters from Wuppertal. In Engels, F. \& K. Marx. Marx \& Engels Collected Works. Volume 2. Moscow: Progress Publishers. 
Foucault, M. 1972. The History of Sexuality: An Introduction. New York: Vintage Press.

Henning, E., W. van Rensburg \& B. Smith 2004. Finding Your Way in Qualitative Research. Pretoria: Van Schaik.

Lacan, J. 1982. The Meaning of the Phallus. na.

Lawn, S.D., L.G. Bekker, K. Middelkoop, L. Myer \& R. Wood 2006. Impact of HIV Infection on the Epidemiology of Tuberculosis in a Peri-Urban Community in South Africa: The Need for Age-Specific Interventions. Clinical Infectious Diseases 42,7: 1040 - 1047.

https://doi.org/10.1086/501018 PMid:16511773

Madge, N., P. Hemming \& K. Stenson 2014. Youth on Religion: The Development, Negotiation and Impact of Faith and Non-faith Identity. London \& New York: Routledge. https://doi.org/10.4324/9781315851068

Marshall, M.N. 1996. Sampling for Qualitative Research. Family Practice 13,6: 522 - 526. https://doi.org/10.1093/fampra/13.6.522 PMid:9023528

Mkhize, Z.V. 2011. Polygyny and Gender: Narratives of Professional Zulu Women in Peri-Urban Areas of Contemporary KwaZulu-Natal. Master's thesis. University of KwaZulu-Natal.

Mkhize, Z.V. 2016. Polygyny and Gender: The Gendered Narratives of Adults Who were Raised in Polygynous Families. PhD Dissertation. University of KwaZulu-Natal.

Muthuki, J.M. 2010. Renegotiation of Gender Identities in Transnational Spaces: The Case of Foreign Students of African Origin at the University of KwaZulu-Natal in Durban South Africa. Saarbrïcken: Lambert Academic Publishing.

Ngidi, E.B. 2012. The Use of Personal Names in Respect of the Living-dead within Traditional Polygynous Families in Kwamambulu, Kranskop. Doctoral dissertation. University of KwaZulu-Natal.

Nnaemeka, O. 2005. The Politics of (M)othering: Womanhood, Identity and Resistance in African Literature. Volume 1. London \& New York: Routledge. https://doi.org/10.4324/9780203981313

Ntshangase, S.Z. 2018. The Power of Dreams and Religious Philosophy of the Zulu People as Portrayed in the Novel, Umshado. South African Journal of African Languages 38,2: 237 - 245.

https://doi.org/10.1080/02572117.2018.1463719 
Ojong, V.B. \& J.M. Muthuki 2010. Religious Conversion and the Renegotiation of Gender Identity Amongst Indian Women in Chatsworth in Durban South Africa. Nidan International Journal for the Study of Hinduism 22: 9 - 20.

Oyewumi, O. 2000. Family Bonds/ Conceptual Binds: African Notes on Feminist Epistemologies. Signs 25,4: 1093 - 1098.

https://doi.org/10.1086/495526

Oyewumi, O. 2002. Conceptualizing Gender: The Eurocentric Foundations of

Feminist Concepts and the Challenges of African Epistemologies. Jenda: A Journal of Culture and African Women's Studies 1: 1 - 5.

Peek, 2005. Becoming Muslim: The Development of Religious Identity. In Sociology of Religion 66,3: 215 - 242. https://doi.org/10.2307/4153097

Peek, L. 2005. Becoming Muslim: The Development of Religious Identity. Sociology of Religion 66, 3: 215 - 242. https://doi.org/10.2307/4153097

Smith, C.P. 2000. Content Analysis and Narrative Analysis. In Reos, J.T. \& C.M. Judd (eds.): Handbook of Research Methods in Social and Personality Psychology. Cambridge: Cambridge University Press.

Stoller, R.J. 1968. Sex and Gender: On the Development of Masculinity and Femininity. London: Hogarth Press.

Sullins, D.P. 2006. Gender and Religion: Deconstructing Universality, Constructing Complexity. American Journal of Sociology 112,3: 838 880. https://doi.org/10.1086/507852

West, C. \& D.H. Zimmerman 1987. Doing Gender. Gender \& Society 1,2: 125 - 151. https://doi.org/10.1177/0891243287001002002

Zeiten, M. 2008. Polygamy: A Cross-Cultural Analysis. New York: Berg Publishers.

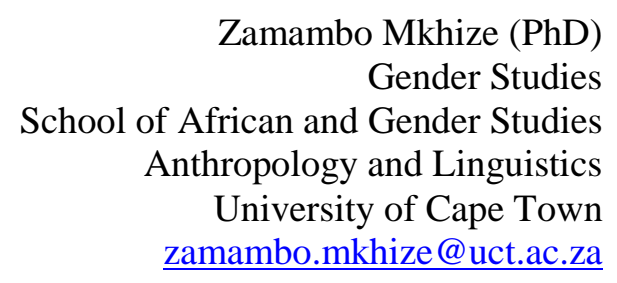

